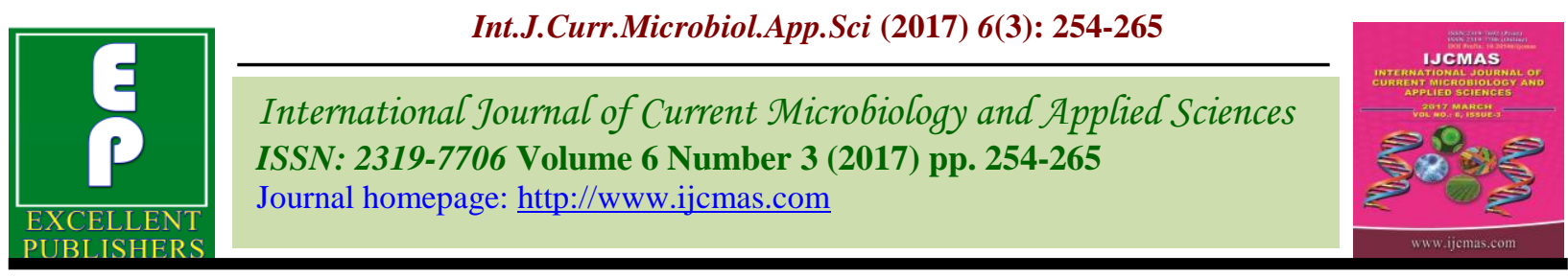

Review Article

https://doi.org/10.20546/ijcmas.2017.603.028

\title{
Integrated Nutrient Management (INM) Approaches in Flower Crops
}

\author{
Muneeb Ahmad Wani ${ }^{1 *}$, Sartaj A. Wani², Malik Sajad Ahmad ${ }^{3}$, \\ Riaz Ahmed Lone ${ }^{1}$, Gazanfer Gani ${ }^{1}$, F.U Khan ${ }^{1}$ and Neelofar ${ }^{1}$ \\ ${ }^{1}$ Division of Floriculture and Landscape Architecture, ${ }^{2}$ Division of Soil Science, ${ }^{3}$ Division of \\ Plant Pathology, Faculty of Horticulture, SKUAST-K, Shalimar Campus, Srinagar 190001, \\ Jammu and Kashmir, India \\ *Corresponding author
}

\section{A B S T R A C T}

\section{Keywords}

Bio-fertilizers, energy, flowers, microbial inoculants, nutrients, INM, yield.

Article Info

Accepted:

10 February 2017

Available Online:

10 March 2017
Sustainable agriculture has become a burning issue due to "energy crisis" and "environmental protection". One aspect of sustainable agriculture is Integrated Nutrient Management (INM). Many regions in India like Kashmir, Himachal and other hilly regions have huge potential for quality flower production. Since floriculture is energy and cost intensive type of farming, the input cost of fertilisers is very high, which can be avoided by going for alternative methods like INM. There is scant information available concerning the use of organic fertilizer as the sole source of nutrients in flower production, especially in the cultivation of flowers has made its applicability more difficult. INM is a practice that is being rapidly adopted by growers, combines the use of adjusted nutrient rates, more efficient fertilizer sources, organic matter and soil inoculation. INM holds great promise in exhibiting the growing nutrient demands of intensive farming like Floriculture and maintaining productivity at its optimum with holistic improvement in the quality of resource base, which is very much important in-case of cut and bulbous flowers. Investigations by many researchers have revealed the beneficial influence of INM, on vegetative (plant height, leaf area, leaf number), floral (first bud appearance, floral diameter, weight of flower) and yield attributes (seed weight, seed production) of many flower crops, reduced the cost of fertilizer inputs and increased the $\mathrm{B} / \mathrm{C}$ ratio, despite maintaining a good soil physico-chemical environment. It can be concluded that by reducing the levels of chemical fertilizer and optimizing the dose of different organic fertilizer can improve yield and quality in ornamental crops without adversely affecting the edaphic and environmental features. Therefore this discourse will mainly discuss on the integrative approaches on production and management of many flower crops, commercially grown in India and Kashmir valley.

\section{Introduction}

Floriculture is a branch of horticulture concerning cultivation of flowering and ornamental plants for gardens and floristry. It includes cut flowers, cut greens, bedding plant, houseplants, flowering garden and potted plants etc. The rising living standards and unabated urbanization in the present day the world has led to growing demand of flowers and their products thereby making the floriculture an important commercial trade. Commercial floriculture has higher potential per unit area than the field crops and is therefore evolving as a lucrative business all over the world (Misra and Sudip, 2016). The area and under floriculture in India are about 
253.65 thousand hectare with production of 1.652 million tonnes loose flowers and 76.73 million tonnes cut flowers (NHB, 2012). Indian floriculture industry stands $2^{\text {nd }}$ in world production (Shilpa and Narpat, 2016) and occupies $51^{\text {Ist }}$ in terms of exports and contributes rupees 455 crores which is 0.06 percent of global trade (De and Singh, 2016). Floriculture has vast scope and potential in Kashmir valley which is evident from the fact that during 1996, an area of 80 hectare was under flower cultivation and has now expanded to 350.0 hectare with an annual turnover of 1350 lac. Further, commercial floriculture engages directly more than 1500 youth in the Valley (Muneeb et al., 2016) and thus offers a unique scope for judicious employment of existing resources and exploration of avenues yet untouched. There is as such an urgent need of scientific approach and wise use to promote the relevant management practices, improvement of flower germplasm, balanced nutrient management, modern production technology, quality planting material, precision farming etc., for conservation and commercialization of the floriculture industry and diversification from the traditional field crops due to higher returns per unit area. The overall strategy for increasing crop yields and sustaining them at high level must include integrated approach to the management of nutrients. The sustainability in agriculture system is a global issue. Integrated nutrient management program is a critical component of the type of integrated farming systems (Edwards et al., 1990). The program involves maximize biological inputs to crop production and minimize the use of inorganic amendments so as to create a much more sustainable pattern of crop production, not only ecologically but also environmentally (National Research Council, 1991). Since the nutrient turnover in soil plant system is considerably high in intensive farming, integrated approach of chemical, organic and biological sources can achieve sustainable production. Practice of INM is the better option for the improvement of physical, chemical and biological properties of soils (Das et al., 2015). To maintain productivity and reduce dependence on chemical fertilizers alone is increasingly becoming important to flower growers. It is important to exploit the potential of organic manures, composts, crop residues, biofertilizers and their synergistic effect with chemical fertilizers for increasing balanced nutrient supply (Wani et al., 2016). This kind of intervention is of paramount importance in horticulture in general and ornamentals in particular. The use of biofertilizers reduces per unit consumption of inorganic fertilizers and increase the quality and quantity of flower (Syamal et al., 2006). The growth and quality of flower are greatly influenced by numerous environmental factors like soil type and nutrient availability being the most essential factors for appropriate growth (Tariq et al., 2012). The quality and production of cut flowers is primarily a varietal trait, it is greatly influenced by climatic, geographical and nutritional factors. The quality and quantity of applied fertilizer are the key factor affecting the growth, yield and quality of the cut flower (Dufour and Guejrin, 2005). The quality of flowers is influenced both by quantity and source of nutrients as well. This paper attempts to review the latest information regarding the role of integrated nutrient management in flower crop production both under both greenhouse as well as open field conditions.

\section{INM investigations in some flower crops}

\section{China aster (Callistephus chinensis Nees)}

In an investigation Chaitra and Patil (2007) assessed integrative response of various fertilizers on flowering and yield attributes of China aster cv. Kamini (Fig. 1). They 
reported that the treatment $\mathrm{T}_{11}(\mathrm{Azo}+\mathrm{PSB}+$ $\mathrm{C}+50 \% \mathrm{RDF}$ ) significantly improved flower diameter, flower yield and the overall yield per unit area. The results strongly endorses the integrative approaches for over all optimum growth and yield inoculation of Azospirillum and PSB, enhanced the cell division and enlargement and also produced growth hormones, which is possible reason for increased growth. These results were inconvenience with the findings of Ravichandran (1991) in crossandra and Mononmani (1992) in jasmine.

\section{Chrysanthemum (Dendranthema $\times$ grandiflora)}

Angadi (2014) evaluated the influence of integrated nutrient management on yield and relative economics of garland chrysanthemum. The reports suggested that (Table 1) yield traits like number of flowers/plant, flower yield/plant and flower yield/ha were significantly higher in treatment $\mathrm{T}_{9}$ (Azospirillum $+\mathrm{PSB}+50$ per cent vermicompost equivalent to $\mathrm{RDN}+50$ per cent recommended NPK). The same treatment also recorded maximum net returns (Rs. 1,95,135/ha) and high $\mathrm{B}: \mathrm{C}$ ratio (4.23) compared to control. This might be due to the beneficial effect of vermicompost and biofertilizers in combination with recommended dose of inorganic fertilizers which lead to better root proliferation, uptake of nutrients and water and better plant growth. This is in conformity to the findings of Chandrikapure et al., (1999) in marigold, Chaitra and Patil (2007) in China aster, Deshmukh et al., (2008) in gaillardia and Meshram et al., (2008) in annual chrysanthemum. This gives a tremendous scope for the yield improvement in garland chrysanthemum with the integrated nutrient management practices. In addition, this study also throws light on reduction in the quantity of chemical fertilizer application when applied along with biofertilizers and organic manures to get yield at par with recommended dose of inorganic fertilizers. The present investigation shows that among all the treatments, the treatment $\left(\mathrm{T}_{9}\right)$ receiving combination of Azospirillum, PSB, 50 per cent vermicompost equivalent to RDN and 50 per cent recommended NPK gave highest flower yield of $(9.65 \mathrm{t} / \mathrm{ha})$ with the maximum net returns per rupee invested (1: 4.2) (Table $1)$.

\section{Rose (Rosa spp.)}

Lambat and Pal (2012) while studying the effects of organic manures and biofertilizers on growth and flowering of Rosa cv. Madgod observed that more length of flower bud (3.03 $\mathrm{cm})$ was obtained when plant treated with neem cake $400 \mathrm{~g}+$ PSB $1 \mathrm{~g}+$ Azotobacter 1 $\mathrm{gm}^{-2}$ and minimum under control $(2.66 \mathrm{~cm})$ as shown in figure 2. Among the treatments maximum flower diameter $(2.50 \mathrm{~cm})$ was observed with neem cake $400 \mathrm{~g}+$ PSB $1 \mathrm{~g}+$ Azotobacter $1 \mathrm{gm}^{-2}$ followed by linseed cake $400 \mathrm{~g} \mathrm{~m}^{-2}+$ PSB $1 \mathrm{~g}+$ Azotobacter $1 \mathrm{~g} \mathrm{~m}^{-2}$ $(2.46 \mathrm{~cm})$. Results revealed that the treatments of organic manures and biofertilizer showed significant influence on flower yield. Plants treated with neem cake $400 \mathrm{~g}+$ PSB $1 \mathrm{~g}+$ Azotobacter $1 \mathrm{gm}^{-2}$ recorded maximum (201.03) number of flowers followed by mustard cake $400 \mathrm{~g}+$ PSB $1 \mathrm{~g}+$ Azotobacter $1 \mathrm{gm}^{-2}$ (166.88). Vase life (6.0 days) of flowers was maximum under neem cake $400 \mathrm{~g}+$ PSB $1 \mathrm{~g}+$ Azotobacter $1 \mathrm{~g}$ $\mathrm{m}^{-2}$. These results are in close line with the findings of Yadav et al., (1989) and Sinha et al., (1981).

\section{Statice (Limonium caspia)}

Gayathri et al., (2004) evaluated the integrative effects of different fertilizers of flowering parameters of statice cv. blue diamond (Fig. 3). The results revealed that the 
treatment T10 $(50 \% \mathrm{NP}+100 \% \mathrm{~K}+\mathrm{VC}+$ Azotobacter + PSB) significantly improved the spike length, spike spread and the number of branches per spike. Significant increase in plant height and spread due to combined application of Azospirillum, PSB and inorganic fertilizers has been reported earlier in Valeriana jatamansi (Salathia, 2005) and gladiolus (Srivastava and Govil, 2005).

\section{Marigold (Tagetes spp.)}

In a study conducted by Sunitha and Hunje (2010), to ascertain the response of integrated nutrient management on growth and yield on African marigold, used different combinations of fertilizes treatments (Fig. 4). The study revealed that the treatment $\mathrm{F}_{5}(50 \% \mathrm{RDF}+\mathrm{VC}$ $(50 \% \mathrm{RDF})$ had a significant effects in the number of flowers per plant and the treatment was at par with that of $F_{3}(R D F+V C 5 t / h a)$. Same trend was observed with that of seed yield per hectare.

The investigation also reported that the an application of vermicompost as $50 \%$ RDN along with $50 \%$ RDF recorded significantly higher plant height, maximum number of primary branches, flowers, seed yield per plant (18.6g) and per hectare $(499.00 \mathrm{~kg}$ compared to RDF alone. Biofertilizerinoculated plants may be ascribed to easy uptake of nutrients and simultaneous transport of growth promoting substances like cytokinin to the axillary buds, resulting in breakage of apical dominance.

Ultimately, this has resulted in a better sink for faster mobilization of photosynthates and early transformation of plant parts from vegetative to reproductive phase. In this way the biofertilizers helped in improving overall growth and yield of marigold. These results were in conformity with the findings of Karuppaiah and Krishna (2005) in French marigold and Jenny Marks et al., (2006) in ajowan.

\section{Tuberose (Polianthes tuberosa)}

Mayuri et al., (2013) evaluated the response of INM on sprouting, plant height, plant spread (E-W and N-S) and number of leaves per clump in tuberose cv. Double (Fig. 5). The data showed significant variation and minimum days for sprouting after cutting (18.47 days), maximum plant height at full bloom stage $(61.67 \mathrm{~cm})$ and plant spread at EW and N-S $(37.93 \mathrm{~cm}$ and $37.07 \mathrm{~cm}$, respectively) were recorded with an application of FYM @ 30 t/ha + PSB @ 2 $\mathrm{g} / \mathrm{m}^{2}+$ Azotobacter $2 \mathrm{~g} / \mathrm{m}^{2}\left(\mathrm{~T}_{13}\right)$. This might be due to better nutrient uptake, photosynthesis, source-sink relationship, besides excellent physiological and biochemical activities due to presence of Azotobacter and PSB. The present finding are in close conformity with findings of Kukde et al., (2006) in tuberose; Gupta et al., (2008) and Ranjan and Mansee (2007) in gladiolus; Khan et al., (2009) in tulip and Bhatia and Gupta (2007) in carnation.

\section{Gerbera (Gerbera jamesonii Bolus ex. Hook)}

In an investigation Keditsu (2012b), evaluated the influence of integrative approach of organic and inorganic manures on flowering and yield attributes of Gerbera jamesonii (Fig. 6). The results suggested significant that treatment $\mathrm{T}_{4}(50 \% \mathrm{RDF}+25 \%$ Cocopith $+25 \%$ Pig manure) improved both flower size/fresh weight of flowers (g) and flower yield (kg/ha).

\section{Gladiolus (Gladiolus grandifloras)}

An investigation was undertaken by Madinatul-Nisa et al., (2016) aimed to evaluate the response of integrative nutrient application on overall yield of gladiolus. Significant differences were observed amongst all the treatments (Table 2). The results endorsed 
that the treatment $\mathrm{T}_{6}$ (Azotobacter 1 litre/10 $\mathrm{kg}+$ Azospirillium 1 litre/10 $\mathrm{kg}+80 \% \mathrm{~N}$ $+100 \%$ PK) significantly improved the number of florets spike ${ }^{-1}$ (14.20), number of spikes $\mathrm{m}^{-2}$ (32.00), corms plant ${ }^{-1}$ (3.2) and corms $\mathrm{m}^{-2}$ (74.70). This may be due to the combined action of biofertlizers and inorganic fertilizers, which resulted in more number of leaves plant ${ }^{-1}$, alternatively resulted in more assimilation of photosynthates towards sink, and there by increased the yield characters
(Dalve et al., 2009; Wani et al., 2015). The maximum weight of corms $\mathrm{m}^{-2}(3.07 \mathrm{~kg})$, weight of cormels plant ${ }^{-1}(22.1 \mathrm{~g})$ and weight of cormels $\mathrm{m}^{-2}(0.53 \mathrm{~kg})$ observed in treatment $\mathrm{T}_{12}$ (VAM $250 \mathrm{~g} \mathrm{~m}^{-2}+$ PSB 1 litre $/ 10 \mathrm{~kg}+80 \%$ $\mathrm{P}+100 \% \mathrm{NK})$. The maximum size $(5.62 \mathrm{~cm})$ of corm plant ${ }^{-1}$ has been reported in treatment $\mathrm{T}_{10}$ (PSB 1 litre/10kg $+80 \% \mathrm{P}+100 \% \mathrm{NK}$ ). The results are in close agreement with those obtained by Singh and Sujahata (1990) and Sehrawat et al., (2003).

Table.1 Effect of integrated nutrient management on yield attributes and economics of garland chrysanthemum

\begin{tabular}{|c|c|c|c|c|c|}
\hline Treatments & $\begin{array}{l}\text { Number } \\
\text { of } \\
\text { flowers/ } \\
\text { plant }\end{array}$ & $\begin{array}{l}\text { Flower } \\
\text { yield } \\
\text { (g/plant) }\end{array}$ & $\begin{array}{l}\text { Flower } \\
\text { yield (t/ha) }\end{array}$ & $\begin{array}{l}\text { Net } \\
\text { returns } \\
\text { (Rs.) }\end{array}$ & $\begin{array}{l}\mathrm{B}: \mathrm{C} \\
\text { ratio }\end{array}$ \\
\hline T1 - Absolute control & 22.87 & 20.43 & 2.27 & 20,600 & 0.57 \\
\hline $\begin{array}{l}\mathrm{T} 2-100 \% \mathrm{RDF}+\mathrm{FYM} \\
(20 \mathrm{t} / \mathrm{ha})\end{array}$ & 35.84 & 57.71 & 6.52 & $1,16,962$ & 2.54 \\
\hline $\begin{array}{l}\text { T3 }-50 \% \text { VC equivalent to } \\
\text { RD`N’ }+50 \% \text { RDF }\end{array}$ & 29.67 & 42.78 & 4.70 & 73,585 & 1.63 \\
\hline $\begin{array}{l}\mathrm{T} 4-\text { Azospirillium }+75 \% \\
\mathrm{RD}^{\prime} \mathrm{N} \text { ' }+100 \% \text { RD`P' and } \\
\text { 'K' }\end{array}$ & 28.26 & 38.32 & 4.20 & 65,839 & 1.62 \\
\hline $\begin{array}{l}\text { T5 - PSB }+75 \% \text { RD`P' + } \\
100 \% \text { RD`N' and 'K' }\end{array}$ & 31.51 & 55.25 & 6.25 & $1,15,814$ & 2.86 \\
\hline $\begin{array}{l}\text { T6 - Azospirillium }+50 \% \\
\text { VC equivalent to RD'N' }+ \\
50 \% \text { RDF }\end{array}$ & 31.34 & 51.55 & 5.73 & 97,360 & 2.12 \\
\hline $\begin{array}{l}\mathrm{T} 7-\mathrm{PSB}+50 \% \mathrm{VC} \\
\text { equivalent to RD`N’ }+50 \% \\
\mathrm{RDF}\end{array}$ & 38.73 & 73.34 & 8.15 & $1,57,860$ & 3.44 \\
\hline $\begin{array}{l}\text { T8-Azospirillium + PSB + } \\
50 \% \text { RD'N' and 'P' + } \\
100 \% \text { D'K' }\end{array}$ & 31.32 & 44.37 & 4.93 & 83,720 & 3.12 \\
\hline $\begin{array}{l}\text { T9- Azospirillium + PSB + } \\
50 \% \text { VC equivalent to } \\
\text { RD'N'+50\% RDF }\end{array}$ & 42.33 & 86.8 & 9.65 & $1,95,135$ & 4.23 \\
\hline S.E. \pm & 0.95 & 1.52 & 0.59 & & \\
\hline C.D. $(\mathrm{P}=0.05)$ & 2.85 & 4.56 & 1.77 & & \\
\hline
\end{tabular}

$\mathrm{FYM}=$ Farm yard manure, $\mathrm{PSB}=$ Phosphate solubilizing bacterium, $\mathrm{VC}=$ Vermicompost, RDF = Recommended dose of fertilizer (150:100:100 NPK kg/ha). 
Table.2 Effect of biofertilizers on yield characters in gladiolus cv. Priscilla

\begin{tabular}{|l|l|l|l|l|l|l|l|l|l|l|}
\hline Treatments & $\begin{array}{l}\text { No. of } \\
\text { florets } \\
\text { spike }\end{array}$ & $\begin{array}{l}\text { No. of } \\
\text { florets } \\
\text { open } \\
\text { at one } \\
\text { time }\end{array}$ & $\begin{array}{l}\text { No. of } \\
\text { spikes } \\
\mathrm{m}^{-2}\end{array}$ & $\begin{array}{l}\text { No. of } \\
\text { corms } \\
\text { plant }^{-1}\end{array}$ & $\begin{array}{l}\text { No. of } \\
\text { corms } \\
\mathrm{m}^{-2}\end{array}$ & $\begin{array}{l}\text { No. of } \\
\text { cormels } \\
\text { plant }^{-1}\end{array}$ & $\begin{array}{l}\text { Weight } \\
\left.\text { of corms }^{-2} \mathrm{~kg} \mathrm{~m}^{-2}\right)\end{array}$ & $\begin{array}{l}\text { Weight } \\
\text { of } \\
\text { cormels } \\
\left(\mathrm{g} \mathrm{plant}^{-1}\right)\end{array}$ & $\begin{array}{l}\text { Weight } \\
\text { of } \\
\text { cormels } \\
\left(\mathrm{kg}^{-} \mathrm{m}^{-}\right.\end{array}$ & $\begin{array}{l}\text { Size } \\
\text { of } \\
\text { orm } \\
(\mathrm{cm})\end{array}$ \\
\hline $\mathrm{T}_{1}$ & 12.60 & 5.10 & 26.00 & 2.13 & 46.83 & 32.60 & 1.40 & 12.9 & 0.28 & 4.73 \\
\hline $\mathrm{T}_{2}$ & 13.53 & 4.40 & 31.00 & 2.73 & 61.13 & 35.50 & 1.90 & 15.5 & 0.34 & 4.78 \\
\hline $\mathrm{T}_{3}$ & 12.85 & 4.73 & 27.50 & 2.55 & 59.13 & 33.25 & 2.44 & 14.3 & 0.32 & 5.31 \\
\hline $\mathrm{T}_{4}$ & 13.80 & 5.20 & 31.50 & 3.05 & 66.66 & 36.45 & 2.76 & 16.4 & 0.35 & 5.04 \\
\hline $\mathrm{T}_{5}$ & 13.05 & 4.50 & 28.50 & 2.63 & 60.66 & 33.85 & 2.17 & 17.5 & 0.40 & 4.91 \\
\hline $\mathrm{T}_{6}$ & 14.20 & 4.23 & 32.00 & 3.20 & 74.70 & 38.10 & 2.35 & 17.6 & 0.41 & 4.67 \\
\hline $\mathrm{T}_{7}$ & 14.13 & 4.03 & 24.00 & 1.70 & 37.86 & 25.80 & 1.40 & 16.8 & 0.37 & 4.88 \\
\hline $\mathrm{T}_{8}$ & 13.13 & 4.60 & 29.00 & 1.90 & 39.83 & 34.20 & 1.71 & 16.7 & 0.36 & 5.35 \\
\hline $\mathrm{T}_{9}$ & 12.93 & 4.70 & 24.50 & 2.30 & 48.23 & 27.10 & 1.79 & 19.1 & 0.45 & 4.81 \\
\hline $\mathrm{T}_{10}$ & 13.30 & 4.33 & 29.33 & 2.83 & 68.86 & 34.50 & 3.33 & 19.0 & 0.43 & 5.62 \\
\hline $\mathrm{T}_{11}$ & 12.03 & 4.80 & 25.50 & 2.43 & 54.30 & 29.05 & 1.81 & 20.6 & 0.46 & 5.01 \\
\hline $\mathrm{T}_{12}$ & 13.40 & 4.93 & 30.50 & 2.93 & 71.30 & 34.80 & 3.07 & 22.1 & 0.53 & 5.37 \\
\hline $\mathrm{T}_{13}$ & 11.20 & 3.50 & 23.50 & 1.20 & 27.26 & 25.20 & 1.26 & 12.5 & 0.28 & 4.50 \\
\hline${\mathrm{C} . \mathrm{D}_{(\mathrm{P} \leq 0.05)}}$ & $\mathbf{1 . 2 1}$ & $\mathbf{0 . 6 5}$ & $\mathbf{2 . 6 1}$ & $\mathbf{0 . 2 7}$ & $\mathbf{6 . 0 5}$ & $\mathbf{1 . 8 0}$ & $\mathbf{0 . 2 5}$ & $\mathbf{1 . 1 0}$ & $\mathbf{0 . 0 9}$ & $\mathbf{0 . 3 3}$ \\
\hline
\end{tabular}

Madinat-ul-Nisa et al., 2016

Fig.1 Influence of biofertilizers, vermicompost with inorganic fertilizers on flowering and yield of China aster cv. Kamini

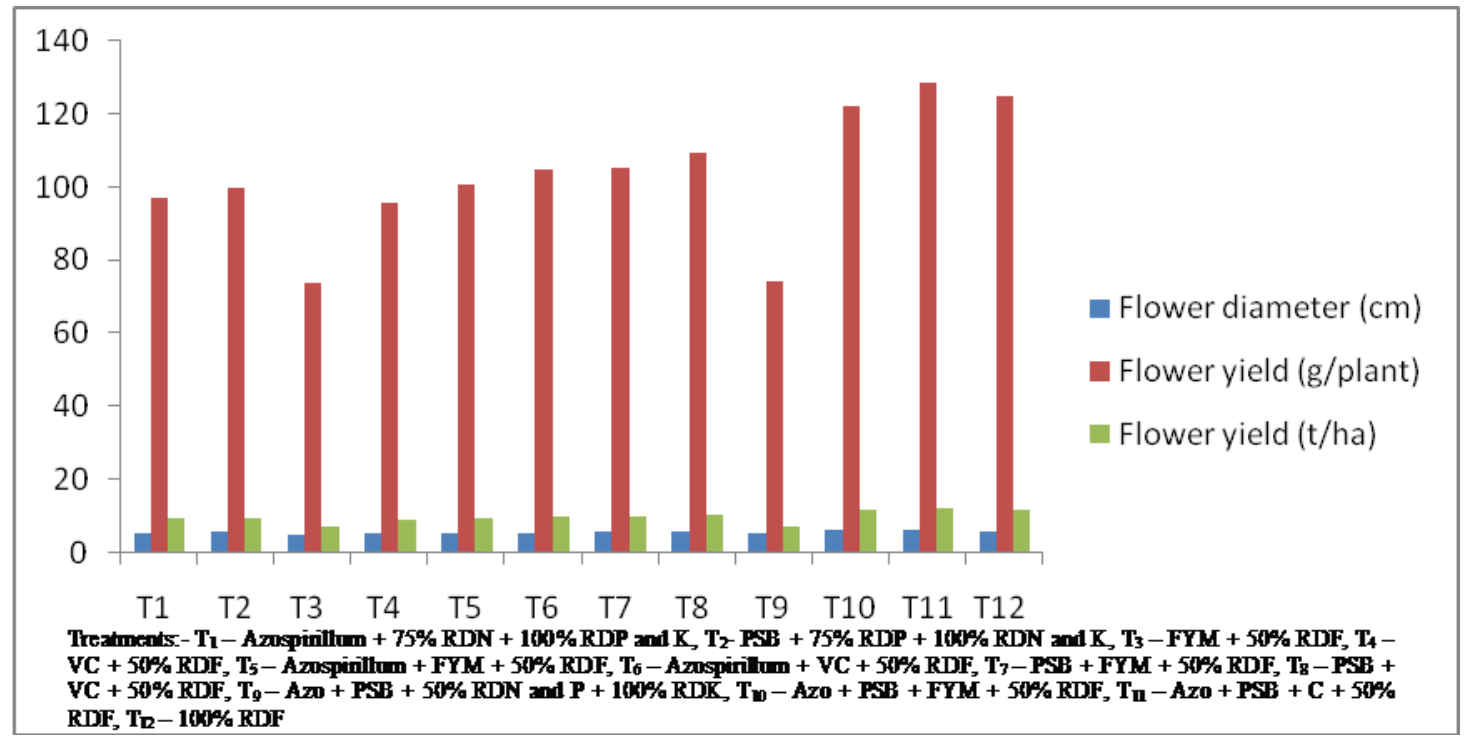

Chaitra and Patil (2007) 
Fig.2 Effect of organic manures and biofertilizer on growth and yield attributes of Rosa cv. Madgod

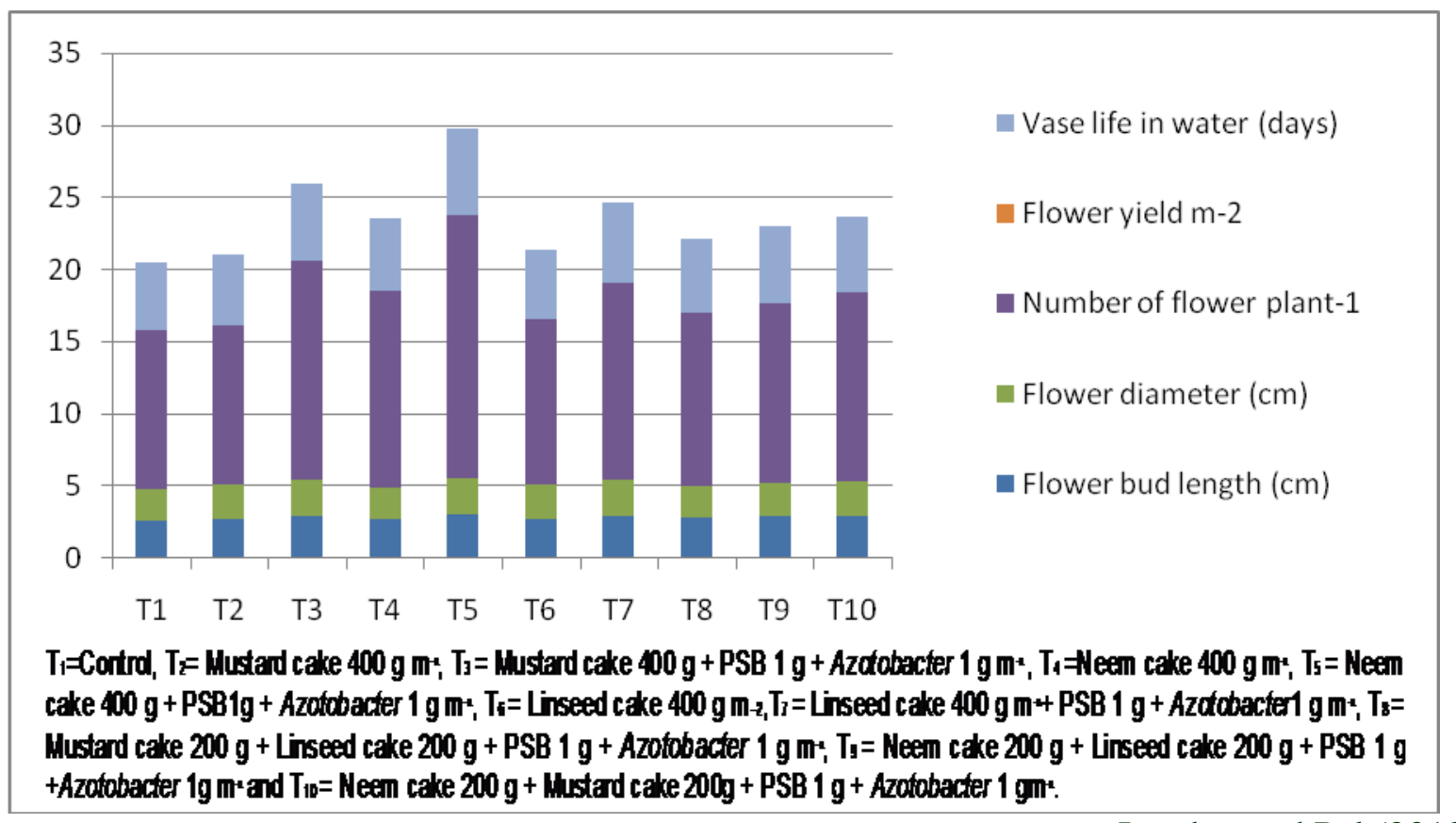

Lambat and Pal (2012).

Fig.3 Influence of bio-fertilizers, vermicompost with different levels of N, P and K on flowering in Statice cv. Blue Diamond

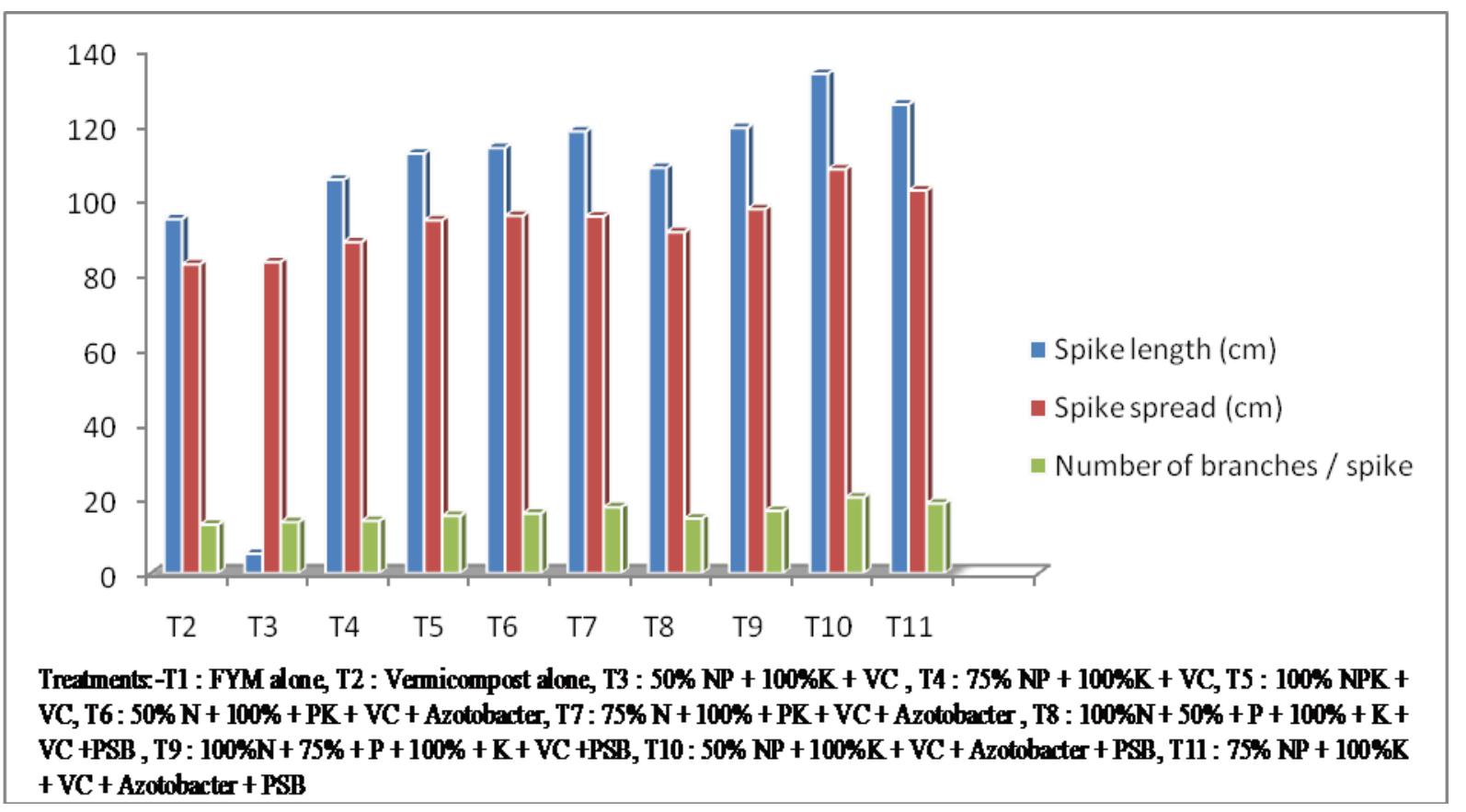

Gayathri et al. (2004) 
Fig.4 Effect of INM on number of flowers per plant and seed yield of African marigold

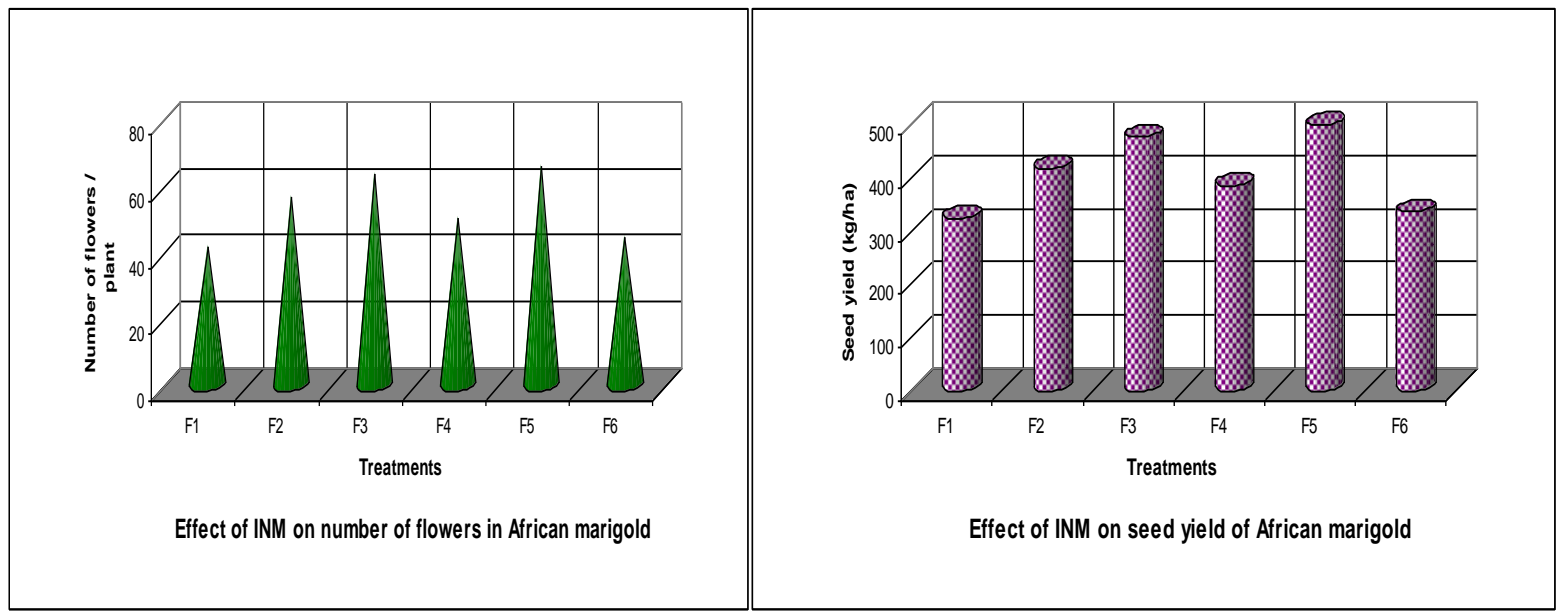

Sunitha and Hunje (2010)

$\mathrm{F}_{1}: \mathrm{RDF}\left(225: 60: 60 \mathrm{~kg} \mathrm{ha}^{-1}\right), \mathrm{F}_{2}: \mathrm{RDF}+\mathrm{FYM} @ 20$ ton ha $^{-1}, \mathrm{~F}_{3}: \mathrm{RDF}+\mathrm{VC} @ 5$ ton ha- ${ }^{-1}, \mathrm{~F}_{4}: 50 \% \mathrm{RDF}+\mathrm{FYM}(50 \% \mathrm{RDN}), \mathrm{F}_{5}: 50 \% \mathrm{RDF}+\mathrm{VC}$ (50\%RDF), $\mathrm{F}_{6}: \mathrm{FYM}(50 \% \mathrm{RDN})+\mathrm{VC}(50 \% \mathrm{RDN})$

Fig.5 Effect of integrated nutrient management on days to sprouting, plant height, plant spread $(\mathrm{E}-\mathrm{W}$ and $\mathrm{N}-\mathrm{S})$ and no. of leaves per clump in ratoon tuberose cv. Double

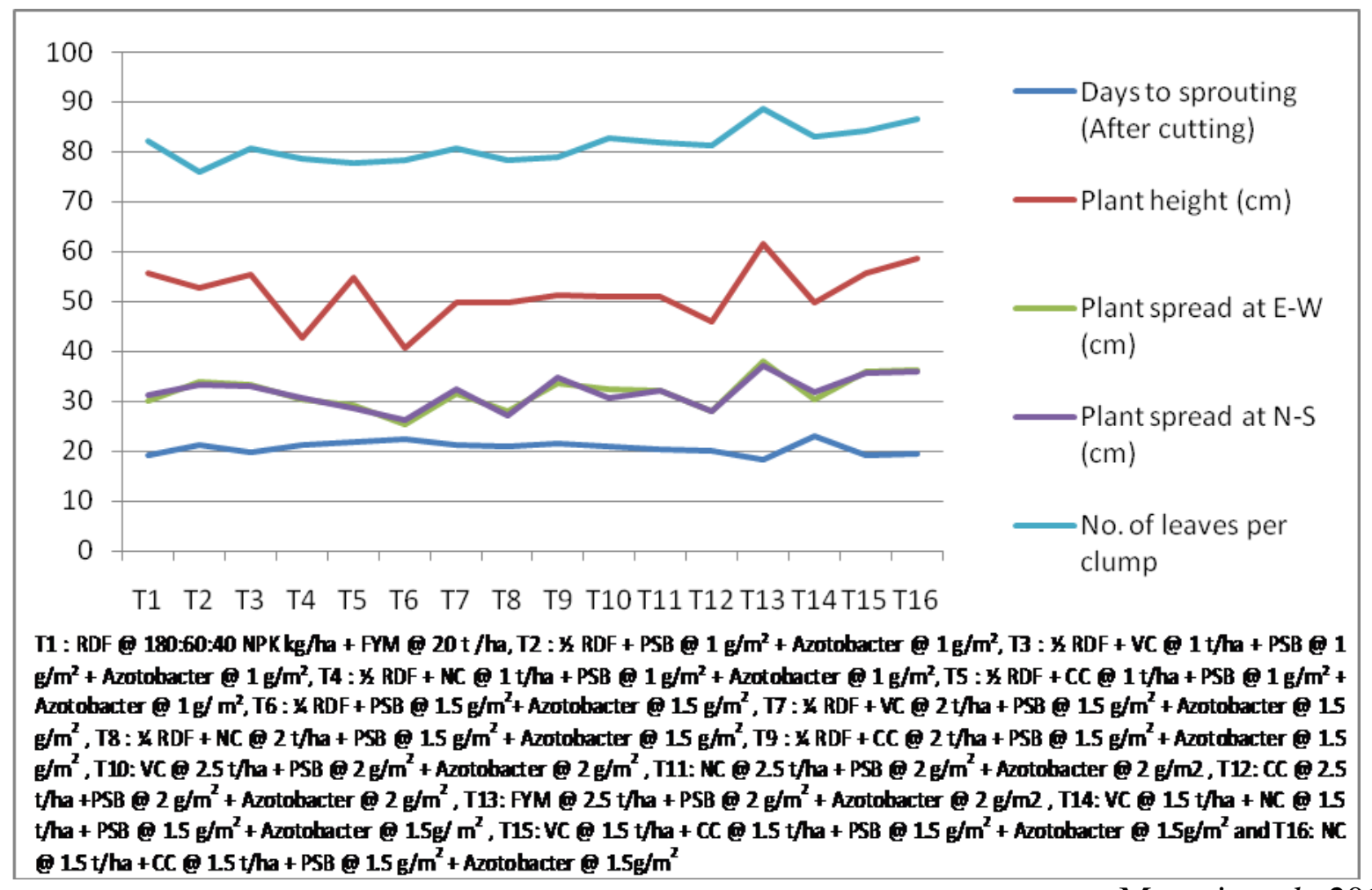

Mayuri et al., 2013 
Fig.6 Effect of INM on flowering and yield parameters of Gerbera jamesonii
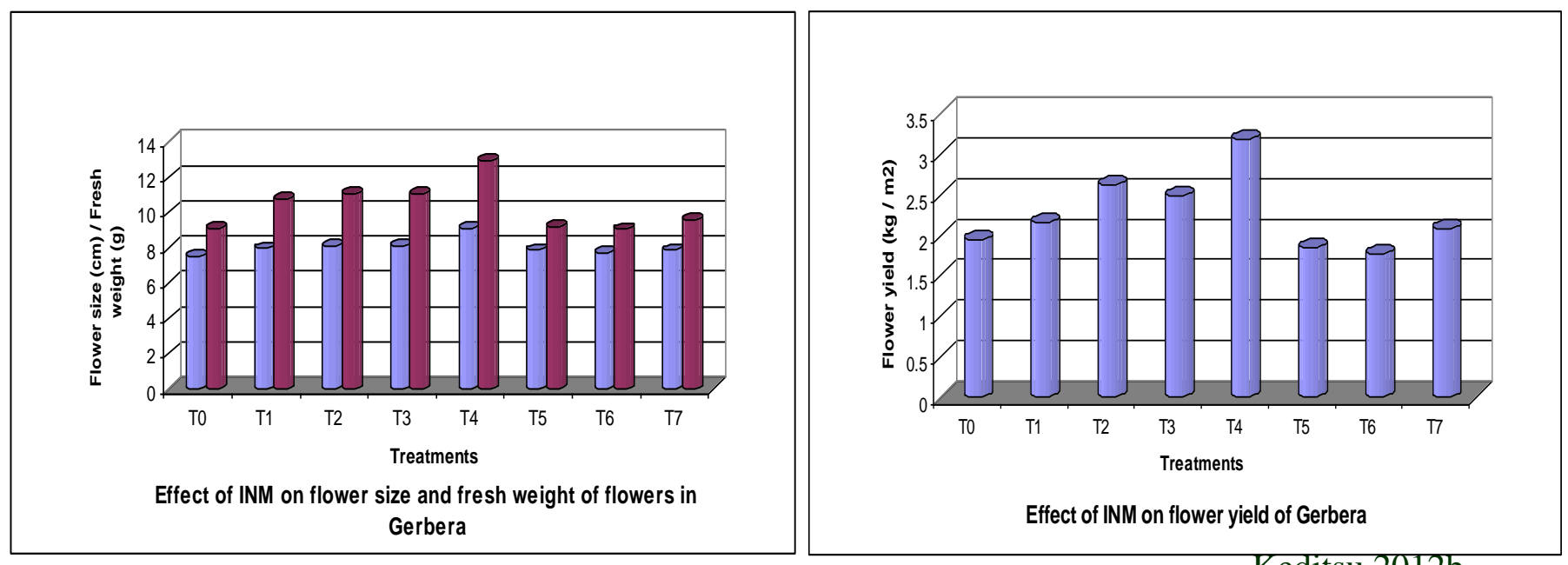

Keditsu $2012 b$

$\mathrm{T}_{0}-100 \%$ RDF (Recommended doses of fertilizers), $\mathrm{T}_{1}-50 \% \mathrm{RDF}+50 \%$ Cocopith, $\mathrm{T}_{2}-50 \% \mathrm{RDF}+50 \%$ Pig manure, $\mathrm{T}_{3}-50 \% \mathrm{RDF}+50 \% \mathrm{FYM}$, $\mathrm{T}_{4}-50 \% \mathrm{RDF}+25 \%$ Cocopith $+25 \%$ Pig manure, $\mathrm{T}_{5}-50 \% \mathrm{RDF}+25 \%$ Pig manure $+25 \% \mathrm{FYM}, \mathrm{T}_{6}-50 \% \mathrm{RDF}+25 \% \mathrm{FYM}+25 \% \mathrm{Cocopith}, \mathrm{T}_{7}-$ $50 \%$ Cocopith $+25 \%$ Pig manure $+25 \%$ FYM

Fig.7 Interaction effect of M x F on growth and bulb production parameters in tulip cv.

\section{Apeldoorn}

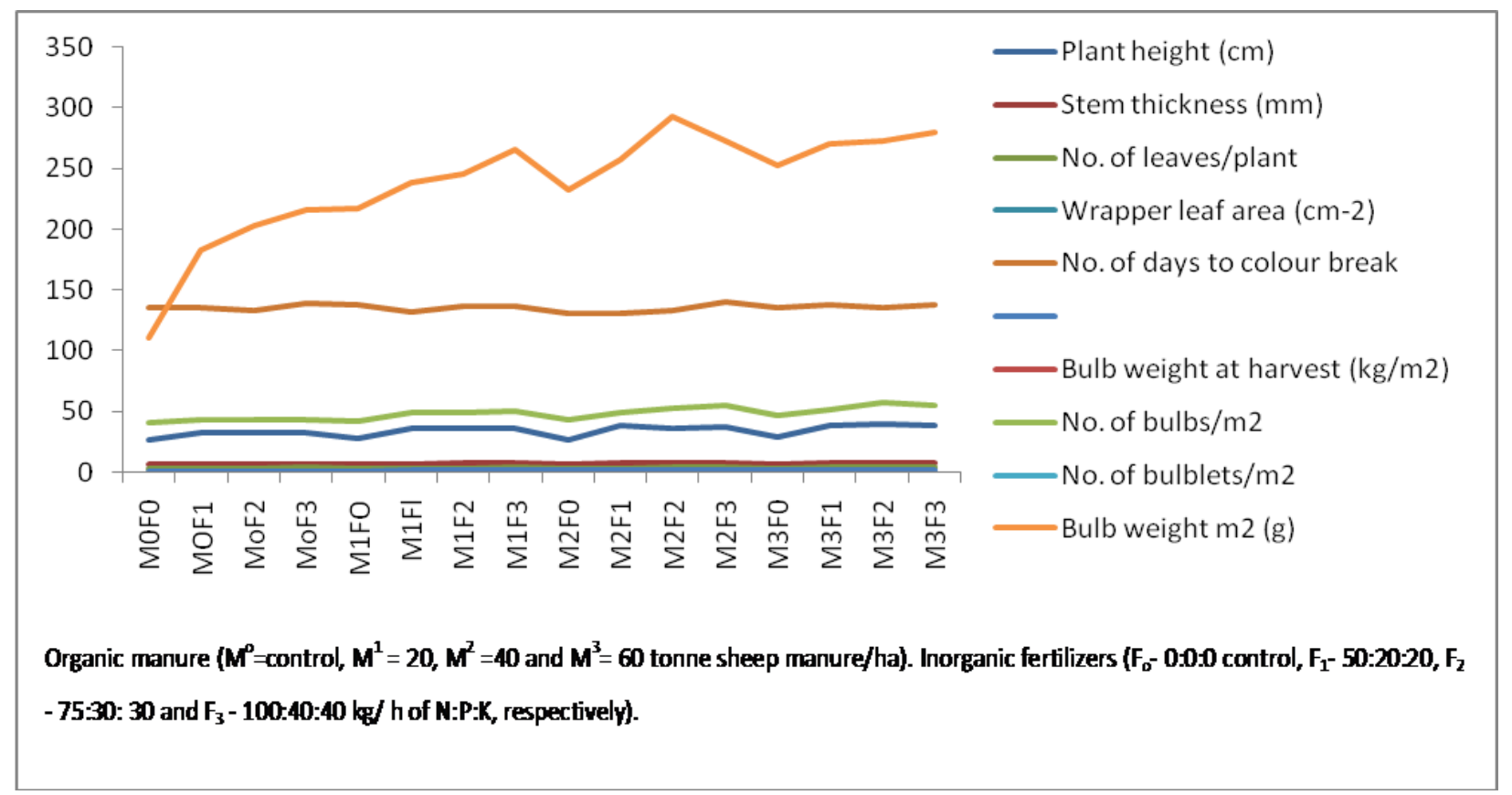

Jhon et al., 2007

\section{Tulip (Tulipa gesneriana L.)}

An experiment was carried out by Jhon et al., (2007) to assess the interaction impact of organic manure and inorganic fertiliser ( $\mathrm{M} \mathrm{x}$ F) on growth and bulb production in tulip cv. Apeldoorn. The results (Fig. 7) unveiled that interaction of organic manure and mineral 
fertility levels showed significant effect on plant height, wrapper leaf area, number of bulbs and their weight, large sized bulbs, number of bulblets and their weight $\mathrm{m}^{-2}$, while number of days taken to and percentage sprouting, stem thickness, number of leaves plant $^{-1}$, days to colour break, bulb weight at harvest. Number of bulbs ranged from 40.50 to $55.50 \mathrm{~m}^{-2}$. They observed that organic manure (60 tonnes $\mathrm{ha}^{-1}$ ) in conjugation with inorganic fertilizers $\left(\begin{array}{lllll}\mathrm{N}_{75} & \mathrm{P}_{30} & \mathrm{~K}_{30} & \mathrm{~kg} / \mathrm{ha}\end{array}\right)$ improved plant height $(39.50 \mathrm{~cm})$, wrapper leaf area $\left(139.77 \mathrm{~cm}^{2}\right)$, total number of bulbs $\left(57.50 \mathrm{~m}^{-2}\right)$, large sized bulbs of $>11 \mathrm{~cm}$ (16.00), 9-11 cm (18.50) circumference and number of bulblets $\mathrm{m}^{-2}(130.50)$.

In conclusion, the increase in the degradation and deterioration of soil physico-chemical properties because of synthetic fertilizers had led find out the natural or alternate methods of soil amendments. Therefore INM strategies are best methods to avoid these problems. INM leads to increased $\mathrm{B} / \mathrm{C}$ ratio, as this approach mainly uses organic sources of fertilizers, being very cheap in cost. Therefore, it can be concluded that by reducing the level of chemical fertilizer and optimizing the dose of different organic fertilizer can optimize the yield in ornamental crops and improve overall soil health without depleting the environment.

\section{Acknowledgements}

Authors wish to express richest gratitude to those researchers/scientists/organizations, whose findings have being inculcated in this manuscript.

\section{References}

Angadi, A.P. 2014. Effect of integrated nutrient management on yield, economics and nutrient uptake of garland chrysanthemum (Chrysanthemum coronarium L.) The Asian $J$. Horticulture, 9(1): 132-135.

Bhatia, Suman and Gupta, Y.C. 2007. Studies on use of biofertilizer in carnation (Dianthus caryophyllus Linn.) flower production. J. Orna. Hort., 10(2): 131132.

Chaitra, R. and Patil, V.S. 2007. Integrated Nutrient Management Studies in China Aster (Callistephus chinensis (L.) Nees) Karnataka J. Agric. Sci., 20(3):689-690.

Chandrikapure, K.R., Sadawarte, D.M., Panchabh and Shelke, B.D. 1999. Effect of bioinoculants and graded doses of nitrogen on growth and flower yield of marigold (Tagetes erecta L. Orissa J. Hort., 27(2): 31-34.

Dalve, P.D., Mane, S.V. and Nimbalkar, R.R. 2009. Effect of biofertilizers on growth, flowering and yield of gladiolus. The Asian J. Horticulture, 4(1): 227-229.

Das, D., Dwivedi, B.S. Meena, M.C. 2015. Integrated Nutrient Management for Improving Soil Health and Crop Productivity Indian J. Fert., 11(4): pp.6483.

De, L.C. and Singh D.R. 2016. Floriculture industries, Opportunities and Challenges in Indian Hills. Int. J. Horticulture, 6(13): 1-9.

Deshmukh, P.G., Khiratkar, S.D., Badge, S.A. and Bhongle, S.A. 2008. Effect of bioinoculants with graded doses of NPK on growth and yield of gaillardia. J. Soils Crops, 18(1): 212-216.

Dufour, L. and Guejrin V. 2005. Nutrient solution effects on the development and yield of Anthurium andreanum Lind. in the tropical soilless conditions. Scientia Horticulturae, 105: 269-282.

Edwards, C.A.R., Lal, P., Madden, R.H. Miller and G. House, G. eds. 1990. Sustainable Agricultural Systems. Ankeny, Iowa: Soil and Water Conservation Society.

Gayathri, H.N., Jayaprasad, K.V. and 
Narayanaswamy, P. 2004. Response of bio-fertilizers and their combined application with different levels of inorganic fertilizers in statice (Limonium caspia. J. Ornamental Horticulture, 7(1): 70-74.

Gupta, Puvinder, Rajwal, Neeraj, Dhaka, V.K and Rajwal, Dheeraj. 2008. Effect of different levels of vermicompost, NPK and FYM on performance of gladiolus (Gladiolus grandiflorus L.) cv. Happy End. Asian J. Horticulture, 3(1): 142143.

Jenny Marks, S., Vyakarnahal, B.S., Shekhargouda, M., Patil, V.S. and Patil, M.S., 2006, Effect of fertilizer and spacing levels on seed yield and its attributes in ajowan. Karnataka J. Agri. Sci., 19(1): 124-126.

Jhon, A.Q. Mir, M.M., Neelofar and Khan, F.U. 2007. Response of organic manure and inorganic fertilizer on growth and bulb production in tulip (Tulipa gesneriana Linn.) J. Ornamental Horticulture, 10(3): 157-160

Karuppaiah, P. and Krishna, G. 2005. Response of spacings and nitrogen levels on growth, flowering and yield characters of French marigold (Tagetes patula Linn. J. Orn. Hort., 8(2): 96-99.

Keditsu, R. 2012b. Response of Gerbera to inorganic fertilization versus organic manuring. Ann. Pl. Soil Res., 14(2): 163166.

Khan, F.U., Siddique, M.A.A., Khan, F.A. and Nazki, I.T. 2009. Effect of biofertilizers on growth, flower quality and bulb yield in tulip (Tulip agesneriana. Indian J. Agri. Sci., 79(4): 248-251.

Kukde, Seema, Pillewan, Shalini, Nammi Meshram, Khobragade, Hemlata and Khobragade, Y.R. 2006. Effect of organic manure and biofertilizer on growth, flowering and yield of tuberose cv. Single. J. Soils Crops, 16(2): 414-416.
Lambat, H.S. and Pal, P. 2012. Effect of organic manures and biofertilizers on growth and flowering of Rosa cv. Madgod. J. Crop and Weed, 8(2):137138.

Madinat-ul-Nisa., K.M Malik and Z.A. Rather. 2016. Effect of biofertilizers on growth, flowering and corm yield in Gladiolus (Tourn.) L. cv. Priscilla. Green Farming, 7(5): 1256-1259.

Manonmani, R. 1992. Effect of soil inoculation of Azospirillum and phosphobacteria and graded level of $\mathrm{N}$ and $\mathrm{P}$ bio-fertilizers on growth and yield of Jasminum sambac Ait. cv. Gundumali. M.Sc. Hort.) Thesis, Tamil Nadu Agricultural University, Coimbatore, T.N. India.

Mayuri, K.H., Varu, D.K., Niketa, P. And Babariya, V.J. 2013. Effect of integrated nutrient management on growth, yield and quality of ratoon tuberose (Polianthes tuberose L.) cv. Double. The Asian J. Horticulture, 8(2): 448-451.

Meshram, N., Badge, S., Bhongle, S.A. and Khiratkar, S.D. 2008. Effect of bioinoculants with graded doses of NPK on flowering, yield attributes and economics of annual chrysanthemum. J. Soils Crops, 18(1): 217-220.

Misra, D., and Sudip, G. 2016. Growth and export status of Indian floriculture: $\mathrm{A}$ review Agri. Rev., 37(1): 77-80.

Muneeb, A. W., Imtiyaz, T. N., Sheikh, M., Neelofar., Shaziya, H and Quadri, .J.A.P. in Agricultural Marketing: Perspectives and Potentials (ed. Anil Bhat;S.P Singh) 209-233 (New India Publishing Agency (nipa), New Delhi - 110034, 2016).doi:10.13140/RG.2.1.4065.2569/1

National Research Council. 1991. Integrated Nutrient Management for Crop Production. Toward Sustainability: A Plan for Collaborative Research on Agriculture and Natural Resource Management. Washington, DC: The 
National Academies Press. doi: $10.17226 / 1822$

NHB (National Horticulture Board). 2012.

Ranjan, S. and Govil, Mansee. 2007. Influence of biofertilizers on growth and flowering in gladiolus cv. American Beauty. Acta Hort., 742: 183-188.

Ravichandran, M. 1991. Chemical and biological regulation on growth and flowering in crossandra. M. Sc. Hort.) thesis, Tamil Nadu Agricultural University, Coimbatore, India.

Salathia, V.S. 2005. Studies on organic cultivation of Valeriana jatamansi. Jones. http://www.yspuniversity.ac.in/fpu/theis/f pu-mscabstracts.doc

Sehrawat, S.K., Dahiya, D.S., Singh, S. and Rana, G.S. 2003. Growth, flowering and corm production in gladiolus as influenced by NPK application. Haryana J. Horticultural Sci., 32(3/4): 222-224.

Shilpa, K. and Narpat, S. 2016. Challenges and Obstacles in Indian Floriculture Industry. Int. J. Innovative Res. Develop., 5(7): 22-24.

Singh, K.P. and Sujatha, K. 1990. Influence of different levels of nitrogen and phosphorus in gladiolus cv. Green Meadow cormel production. South Indian Horticulture, 38(4): 208-210.

Sinha, N.P., Prasad, B. and Ghosh, A.B. 1981. Effect of continuous use of fertilizers on yield and nutrient uptake in wheat, soybean, potato cropping system. $J$. Indian Soc. Soil Sci., 29: 537-42.

Srivastava, R. and Govil, M. 2005. Influence of biofertilizers on growth and flowering in gladiolus cv. American Beauty. ISHS Acta Horticulture 742: International Conference and Exhibition on Soil less Culture (ICESC)

Sunitha, H.M. and Hunje, R. 2010. Effect of plant population and integrated nutrient management on growth, seed yield and quality of African marigold (Tageteserecta L. Karnataka J. Agric. Sci., 23(5): 783-786.

Syamal, M.M., Dixit, S.K. and Kumar, S. 2006. Effect of bio-fertilizers on growth and yield in marigold. J. Ornamental Horticulture, 9(4): 304-305.

Tariq, U., S. Rehman, M.A. Khan, A. Younis, M. Yaseen and M. Ahsan, 2012. Agricultural and municipal waste as potting media components for the growth and flowering of Dahlia hortensis "Figaro". Turkish J. Bot., 36: 378-385.

Wani, M. A., Nazki, I. T. and Din, A. (2015). Effect of split application of ammoniacal and nitrate sources of nitrogen on lilium growth and yield. Journal of Plant Stress Physiology. 1(1):7-12.

Wani, S.A., Ali, T., Chand, S. and Sofi, K.A. 2016. Improving soil health and productivity in brown sarson var. KS-101 (Brassica rapa L.) in alfisols of temperate Kashmir through organic and inorganic nutrient sources. Ecol. Environ. Conservation, 22: 21-22.

Yadav, L.P., Dadlani, N.K. and Malik, R.S. 1989. Rose in Commercial Flowers (Eds.Yadav, L. P. and Bose, T. K.), Naya Prokash, Kolkata, West Bengal, pp. 18150.

\section{How to cite this article:}

Muneeb Ahmad Wani, Sartaj A. Wani, Malik Sajad Ahmad, Riaz Ahmed Lone, Gazanfer Gani, F.U Khan and Neelofar. 2017. Integrated Nutrient Management (INM) Approaches in Flower Crops. Int.J.Curr.Microbiol.App.Sci. 6(3): 254-265. doi: https://doi.org/10.20546/ijcmas.2017.603.028 